\title{
Suspended Solids from Drained Peatlands in the East Coastal Zone of New Brunswick: Point Estimates and Climate Effects on the Environment
}

\author{
Mathieu Quenum, Marion Tetegan and Papa Malick Sall \\ Department of Peat, Peatlands and Sustainable Development, Coastal Zones Research Institute, Shippagan E8S1J2, Canada
}

\begin{abstract}
Peatlands represent one of the most important economic resources and abandoned peatlands after mining can be considered as ecological resources by re-vegetation restoration or management. However, some environmental problems like particles from peatlands and their effects in the water system have to be characterized. Since centuries, artificial drainage has been a current practice for the mining of peatlands. Mainly mined for horticultural purpose, New Brunswick's peatlands-predominantly located in the eastern of the province - cover about 140,000 ha. At the downstream end of the drainage system, the water from peatlands flow into sedimentation basins. Drainage waters are often laden with solid particles. Once they have flowed through the ponds to allow sediment settling, the water is released into the water system. This paper describes the spatio-temporal evolution of suspended solids from 12 New Brunswick drained peatlands. The studied sites were characterized by some heterogeneity in the concentration of suspended solids. This study also provides knowledge on the suspended solids amount that can be released by drained peatlands, and it proposes a function to estimate the concentration of suspended solids by using climate variables; and identifies some potential ecological risks.
\end{abstract}

Key words: Peatlands, drainage, sedimentation ponds, suspended matters, water system.

\section{Introduction}

Peatlands are organic soils constituting $3 \%$ of the land surface of the globe [1]. These approximately 400 million ha are located primarily in North America (about 37\% in Canada) and in boreal areas of Asia and Europe (Fig. 1). These types of lands are ecologically distinctive because they are characterized by wetlands with very high carbon stocks. This high carbon content is mostly concentrated in a soil layer mainly composed of more or less degraded organic matter. Considering all the peatlands on earth, these carbon stocks-about $500 \times 10^{9} \mathrm{t}$-surpass those of other terrestrial ecosystems. This wealth leads to various human uses. Clarke and Joosten [2] revealed that around 80 million ha of peatlands are used for forestry, agriculture, paludiculture, and mining (Fig. 1). With

Corresponding author: Mathieu Quenum, Ph.D., scientific director, research fields: agronomy, soil, water and environmental science. E-mail: mathieu.quenum@umoncton.ca. more than 110 million ha of peatlands widely distributed on all the Canadian territory, Canada is considered as one of the major producers and exporters of peat, mainly for commercial horticultural peat moss-based substrates. In New Brunswick, the exploitation is primarily for the production of growing media and soil amendments for the horticulture industry. Presently, less than $5 \%$ of the Canada's peatlands are operated, which corresponds to 5,500 ha; and from the 800 peatlands of New Brunswick, only 60 are exploited by about 25 companies in 2012. The operation of sites is mainly located in the Acadian Peninsula.

Peatlands exploitation requires drying of the harvested layers by water drainage. Despite best practices for drain-blocking techniques on blanket peat, peatlands drainage causes several problems [3]. The main ecological problems are biodiversity disturbance, greenhouse gas emissions, and soil 


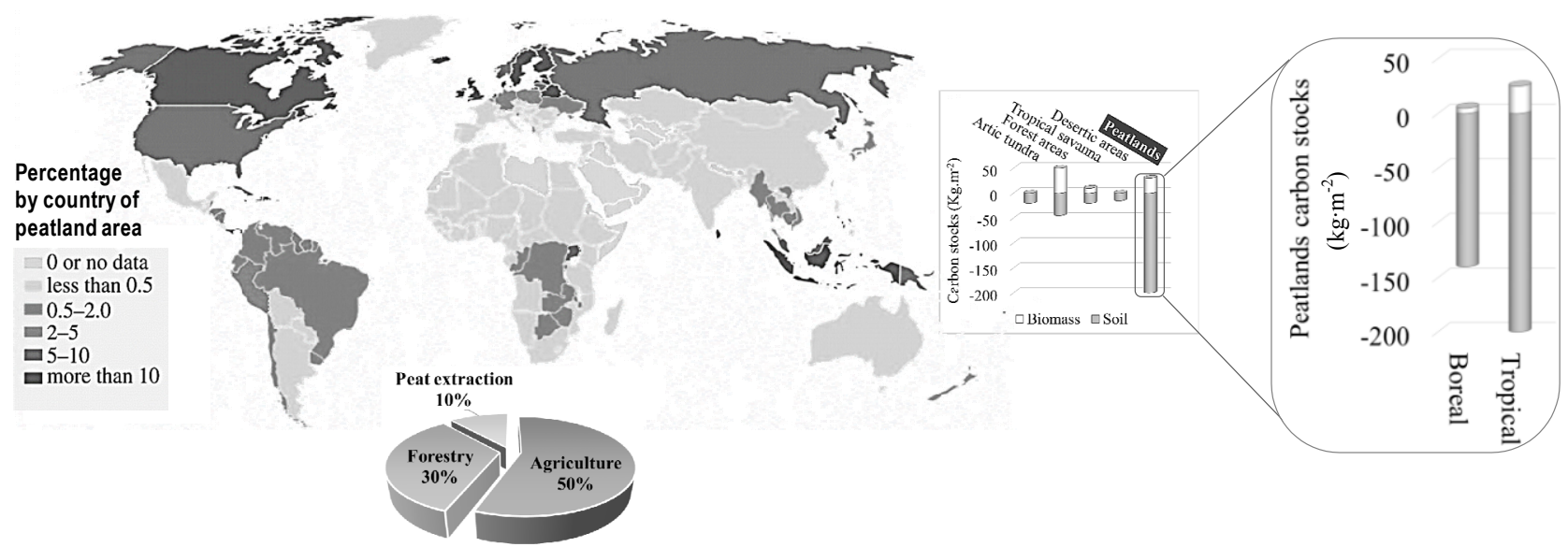

Fig. 1 Global peatlands area in percentage by country, main peat uses and peatlands carbon stocks (modified from Refs. [4, 5]).

degradation. Several studies show that the sustaining of biodiversity can critically be disturbed by the drainage of peatlands [6]. In 2014, Whatley et al. [7] demonstrate that after the peatlands drainage, peat degradation induces a decline in submerged macrophytes leading to diminish the richness and densities of benthic invertebrate species.

Many studies related to greenhouse gas emissions focus on carbon dioxide. From 1990 to 2008, the total $\mathrm{CO}_{2}$ emissions from degrading peatlands are estimated from $1.06 \times 10^{6} \mathrm{t}$ to $1.23 \times 10^{6} \mathrm{t}$ per year. The emissions from peatlands drained for peat extraction before 2008 is evaluated at $1.26 \times 10^{6} \mathrm{t}$ per year. Concerning Canada, this latter type of emissions corresponded to $0.16 \times 10^{6} \mathrm{t}$ per year in 2008 [8]. Hooijer et al. [9] conclude that greenhouse gas emissions are still significant even at the highest theoretical levels of water table. On the contrary, the laboratory experiments of Moore and Knowles [10] demonstrate a linear relationship between the increase of $\mathrm{CO}_{2}$ emissions and a decrease of the level of the water table. Thus, the drainage of peatlands can greatly increase the global warming potential. Indeed, a regional study on drained peatlands in Belarus establishes - with a closed chamber approach-the influence of water table, land use, and annual weather conditions on the greenhouse gases emissions [11]. With a study on drained peatlands in southeast Asia,
Hooijer et al. [12] alert on the increasing contribution of $\mathrm{CO}_{2}$ emission from peatlands drainage to those at global scale. A modelling approach in Ref. [13] also confirms the continuity of these predictions for decades.

Soil degradation of peatlands is also one result of the artificial drainage. After the drainage, several changes occur on hydrological, chemical, and physical properties of the soils of the drained peatlands $[14,15]$. More recently, Kechavarzi et al. [16] focus their work on the physical and hydraulic properties induced by the drainage of residual peatlands; and they reveal that soil alterations have a great influence on the porosity and then on the hydraulic transfers in the medium. Peat soils degradation can be noticed through nutrient losses, modifications in $\mathrm{pH}$ level and bulk density $[17,18]$. Peatlands degradation and that of the surrounding water quality can worsen with future climate change, the latter being able to greatly contribute to strengthening the importance of rill erosion during rainfall events [19]. By studying the runoff from blanket peat, Holden and Burt [20] demonstrate that disturbed peatlands are susceptible to generate higher suspended solids rates through hydraulic flow from deeper peat layers. Also, any physical alterations on peatlands will certainly disturb its overall hydrological behavior and favor runoff events [21]. 
It is increasingly becoming required to assist the peat industries to find alternatives to avoid ecological troubles caused by the peatlands drainage and the peat extraction. To limit the environmental damage associated to the post-drainage of peatlands, the use of buffer zones and sedimentation basins establishment seems to be part of the best options. Buffer zones can be used to reduce the amount of suspended solids produced from drained peatlands, at the condition of creating these buffer zones on large areas (more than 1 ha) [22]. There are several types of managed wetlands, some of which are associated with retention ponds: sustainable flood retention wetland, aesthetic flood treatment wetland, integrated flood retention wetland and natural flood retention wetland [23, 24]. These basins hold the water drainage to prevent it from direct flowing into the surrounding natural water system. Indeed, the water drainage from peatlands is composed by vegetable and mineral particles which can affect water quality, among other things by enhancing the dissolved organic carbon loss, by altering the color of the water, by increasing water turbidity, by encouraging further sediments deposition, and by causing further eutrophication of aquatic ecosystems [25, 26]. Thereby, sedimentation basins act as holding tanks allowing the deposition of suspended solids by gravity in a buffer zone before the water returns to the natural environment.

In New Brunswick, mined peatlands located in the east coastal zone are equipped with sedimentation basins. To evaluate the effectiveness of the retention basins implanted, a chronological survey-2008 to 2012-of the concentration of suspended solids is made. For each of the 5 years considered, the monitored period is lasted from June to September. The calculated suspended solids concentrations are then correlated with climate events and peatlands characteristics. The ecological impacts due to suspended solids in the hydrographic network are also discussed.

\section{Material and Methods}

Located in the east of New Brunswick, mainly distributed along the coast, the studied sites were 12 peatlands actually mined for commercial horticultural peat moss-based substrates extraction (Fig. 2).

Undifferentiated mineral soils are present under the layer of peat deposits [27]. The studied peatlands are under a cool and wet maritime climate with a heavy rainfall [28]. The location, the total area, the mean value of the slope, the year of the beginning of the drainage, and the nearest weather station of all the 12 sites are given in Table 1 .

Knowing that the concentrations of suspended matter from drained peatlands are usually higher in summer, the study interest focused on data collected from June to September of years 2008 to 2012 [29, 30]. A non-random sampling was done and composed of two populations of data. $1 \mathrm{~L}$ of water was sampled from the outlet of the sedimentation basin, delicately avoiding to brew water during sampling in a large opening plastic bottle. A sample was taken twice a month (one every 2 weeks) in normal weather conditions. But in case of heavy rain (more than $25 \mathrm{~mm}$

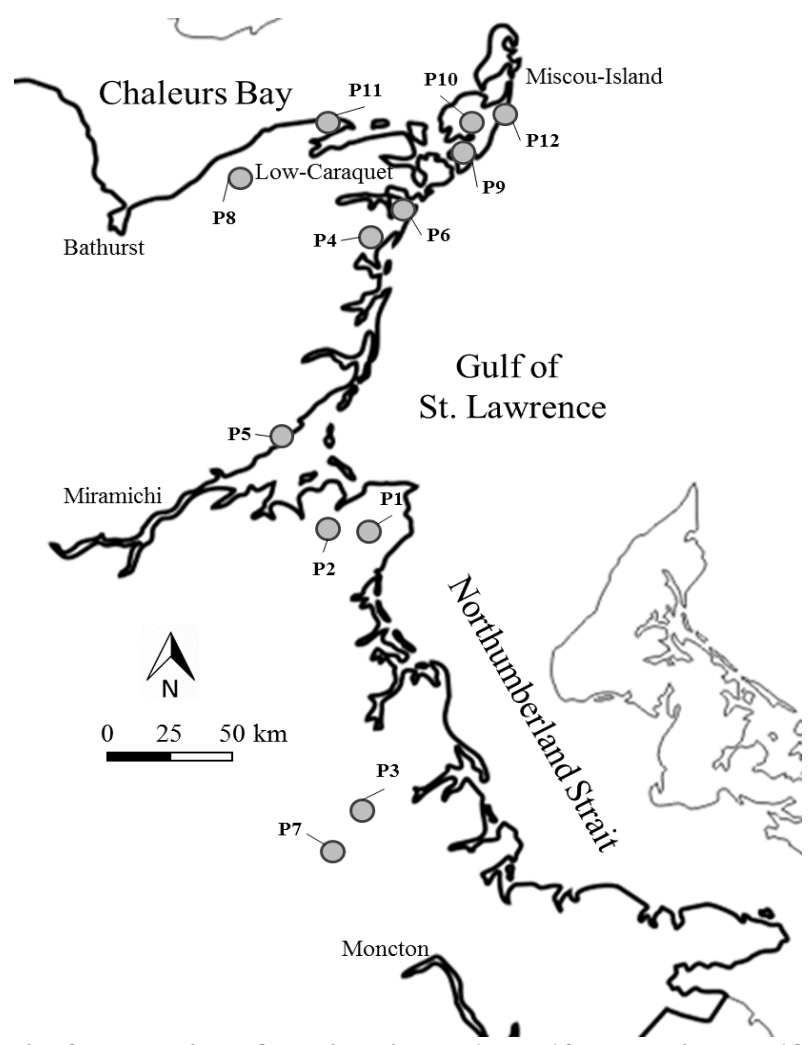

Fig. 2 Location of studied sites. P1 to P12 symbolize the 12 studied drained peatlands. 
Table 1 Some characteristics of studied sites.

\begin{tabular}{|c|c|c|c|c|c|c|}
\hline \multirow{2}{*}{ Peatlands } & \multicolumn{2}{|c|}{ Geographic coordinates } & \multirow{2}{*}{-Total area (ha) } & \multirow{2}{*}{$\begin{array}{l}\text { Approximate year of } \\
\text { drainage }\end{array}$} & \multirow{2}{*}{$\begin{array}{l}\text { Slope } \\
\text { (mean value }(\%))\end{array}$} & \multirow{2}{*}{$\begin{array}{l}\text { Nearest weather station } \\
\text { considered }\end{array}$} \\
\hline & $\mathrm{N}$ & $\mathrm{W}$ & & & & \\
\hline P1 & 47.003729 & -64.913883 & $2,950.70$ & 1960 & nd & Miramichi \\
\hline $\mathrm{P} 2$ & 46.988743 & -65.026492 & 680.39 & 1998 & nd & Miramichi \\
\hline P3 & 46.372367 & -65.025749 & 73.89 & 2006 & nd & Miramichi \\
\hline P4 & 47.596577 & -64.927140 & 265.89 & 2006 & 1.51 & Low-Caraquet \\
\hline P5 & 47.181138 & -65.160388 & 328.68 & 1990 & nd & Miramichi \\
\hline P6 & 47.625278 & -64.845429 & 587.38 & 1954 & 1.97 & Low-Caraquet \\
\hline P7 & 46.327934 & -65.050125 & 382.89 & 1983 & nd & Miramichi \\
\hline P8 & 47.726457 & -65.338765 & 403.11 & 2003 & nd & Low-Caraquet \\
\hline P9 & 47.753009 & -64.636155 & $1,241.31$ & 1951 & 6.55 & Miscou-Island \\
\hline P10 & 47.827491 & -64.620877 & 225.89 & 1969 & 7.16 & Miscou-Island \\
\hline P11 & 47.826820 & -65.041447 & 505.41 & 1964 & 6.66 & Low-Caraquet \\
\hline $\mathrm{P} 12$ & 47.861593 & -64.513074 & 289.19 & 1979 & 6.46 & Miscou-Island \\
\hline
\end{tabular}

P1 to P12 symbolize the peatlands; nd: not determined.

in $24 \mathrm{~h}$ ), water was sampled the day following the rain event. It was the same for the days of high winds (from $60 \mathrm{~km} \cdot \mathrm{h}^{-1}$ for at least $1 \mathrm{~h}$, or gusts from 90 $\mathrm{km} \cdot \mathrm{h}^{-1}$ ) that could cause considerable wind erosion of peat. The sample of water was analyzed the same day of the sampling. At the laboratory, for each water sample, the total suspended solids dried at $103-105^{\circ} \mathrm{C}$ was estimated by applying the $2540 \mathrm{D}$ method from Ref. [31]. Precipitations and wind data were uploaded from the nearest weather stations from studied sites: Miscou-Island $\quad(48.008890 \quad \mathrm{~N}, \quad-64.494170 \quad$ W), Low-Caraquet $(47.802220 \mathrm{~N},-64.833330 \mathrm{~W})$ and Miramichi (47.009440 N, -65.465000 W) [32].

On the data obtained, the basic data treatments were carried out with analysis tool pack in Microsoft Excel 2013 (Microsoft, Seattle, Washington) software package: calculations of mean, median, maximum, minimum and numbers of samples. Weather data are presented in tables with sparkline graphs (a tiny visual representation of data allowing to monitor trends in a serie of values). A correlation matrix was established to evaluate the degree of (non)linearity of the variables. The coefficient of correlation $(R)$, the coefficient of determination $\left(R^{2}\right)$, the $M A E$ (mean absolute error) and the MAPE (mean absolute percentage error) of a multiple linear regression were also calculated to verify the link between the monthly average CSS (concentration of suspended solids), the monthly average speed of the winds $(W)$, the mean value of the slope of peatland $(S)$, and the monthly accumulated precipitations $(P)$ on the drained peatlands. The $S E$ (standard error) of the estimate of the $C S S$ calculated by the function using $W, S$ and $P$ has also been calculated. With $n$, the number of sample; $x$, the measured value; $y$, the forecast value; and $\bar{x}$ and $\bar{y}$, the mean values of $x$ and $y$; the $M A E$, the $M A P E$, and the $S E$ are estimated by Eqs. (1)-(3):

$$
\begin{gathered}
M A E=\frac{1}{n} \sum_{i=1}^{n}\left|y_{i}-x_{i}\right| \\
M A P E=\frac{1}{n} \sum_{i=1}^{n}\left|\frac{x_{i}-y_{i}}{x_{i}}\right| \\
S E=\sqrt{\frac{1}{(n-2)}\left[\sum(y-\bar{y})^{2}-\frac{\left[\sum(x-\bar{x})(y-\bar{y})\right]^{2}}{\sum(x-\bar{x})^{2}}\right]}
\end{gathered}
$$

Comparisons between sites, years and months were done. For all the three types of comparison, a covariance analysis has revealed a dependence between variables to compare. Thus, Friedman tests were performed. Corresponding to a non-parametric analysis of variance, the Friedman test compares the averages of several dependent groups. With a significance level, $\alpha$ equals to 0.05 , the defined hypotheses are $\mathrm{HO}$ and $\mathrm{H} 1$ : for $\mathrm{H} 0$, there was no 
difference between samples; and for $\mathrm{H} 1$, there was a difference between samples. The result of the Friedman test will be presented by given in brackets the Chi square $\left(\chi^{2}\right)$, the degree of freedom $(d f)$ and the $p$ value $(p)$.

\section{Results}

\subsection{Suspended Solids Concentrations}

The concentrations of suspended solids in waters of the majority of samples meet the standard recommended by the Canadian Council of Ministers of the Environment, with results of no more than 25 $\mathrm{mg} \cdot \mathrm{L}^{-1}$ above natural levels on average (Table 2 and Fig. 3) [33]. The trends varied from one site to another, but from the 12 sedimentation basins, only four showed a $C S S$ exceeding $25 \mathrm{mg} \cdot \mathrm{L}^{-1}$ for some months: P2, P3, P5 and P8. The highest and the lowest concentrations of suspended solids were recorded at $61.75 \mathrm{mg} \cdot \mathrm{L}^{-1}$ in July 2010 for $\mathrm{P} 5$, and at $0 \mathrm{mg} \cdot \mathrm{L}^{-1}$ in September 2008 for P7, respectively (Table 2 and Fig. 3).

For P1, with close values of mean and median $\left(10.94 \mathrm{mg} \cdot \mathrm{L}^{-1}\right.$ and $\left.10.00 \mathrm{mg} \cdot \mathrm{L}^{-1}\right)$, the concentrations of suspended solids varied from $2.50 \mathrm{mg} \cdot \mathrm{L}^{-1}$ recorded in July 2009 to $21 \mathrm{mg} \cdot \mathrm{L}^{-1}$ measured for June 2008. For $\mathrm{P} 2$, the minimum value of the concentrations of suspended solids has been measured in September 2012 at $2.00 \mathrm{mg} \cdot \mathrm{L}^{-1}$. The $25 \mathrm{mg} \cdot \mathrm{L}^{-1}$ standard recommended was respected with values smaller than or equal to $18.50 \mathrm{mg} \cdot \mathrm{L}^{-1}$ unless in June and July 2011, months for which the concentrations of suspended solids were estimated at $33.50 \mathrm{mg} \cdot \mathrm{L}^{-1}$ and 39.00 $\mathrm{mg} \cdot \mathrm{L}^{-1}$, respectively. With a lowest concentration of suspended solids estimated at $2.00 \mathrm{mg} \cdot \mathrm{L}^{-1}$ in September 2011 for $\mathrm{P} 3$, the $25 \mathrm{mg} \cdot \mathrm{L}^{-1}$ standard recommended was also mostly respected with values smaller than or equal to $18.00 \mathrm{mg} \cdot \mathrm{L}^{-1}$ unless in June 2008 (28.00 $\left.\mathrm{mg} \cdot \mathrm{L}^{-1}\right)$ and September $2010(37.00$ $\left.\mathrm{mg} \cdot \mathrm{L}^{-1}\right)$. $\mathrm{P} 4$ was one of the sites with the lowest values of concentrations of suspended solids always inferior or equal to $11.00 \mathrm{mg} \cdot \mathrm{L}^{-1}$ with a minimum value at $2.00 \mathrm{mg} \cdot \mathrm{L}^{-1}$ recorded in September 2008, September 2009 and July 2011. At P5, the majority of values of concentrations of suspended solids was lower than $19.00 \mathrm{mg} \cdot \mathrm{L}^{-1}$. In June 2010 , the concentration of suspended solids was equal to $25 \mathrm{mg} \cdot \mathrm{L}^{-1}$ and this threshold was exceeded in July $2010\left(61.75 \mathrm{mg} \cdot \mathrm{L}^{-1}\right)$, July $2011\left(28.00 \mathrm{mg} \cdot \mathrm{L}^{-1}\right)$, and June $2012(30.00$ $\left.\mathrm{mg} \cdot \mathrm{L}^{-1}\right)$.

All the measured values at P6 were lower than $24.88 \mathrm{mg} \cdot \mathrm{L}^{-1}$, with a minimum value of concentrations of suspended solids at $0.50 \mathrm{mg} \cdot \mathrm{L}^{-1}$ in August 2008 . Similar to P4, P7 was also one of the sites with the lowest estimations of suspended solids always inferior or equal to $12.00 \mathrm{mg} \cdot \mathrm{L}^{-1}$ with a null minimum value in September 2008. For P8, the concentrations of suspended solids varied from $2.17 \mathrm{mg} \cdot \mathrm{L}^{-1}$ recorded in September 2011 and $56.00 \mathrm{mg} \cdot \mathrm{L}^{-1}$ measured for June 2012; aside from June 2012, the $25 \mathrm{mg} \cdot \mathrm{L}^{-1}$ standard recommended was not respected in September 2008 $\left(27.33 \mathrm{mg} \cdot \mathrm{L}^{-1}\right)$. For $\mathrm{P} 9$, the concentrations of suspended solids varied between $2.83 \mathrm{mg} \cdot \mathrm{L}^{-1}$ and $15.33 \mathrm{mg} \cdot \mathrm{L}^{-1}$, respectively estimated in June 2010 and August 2012. For P10, with almost homogeneous

Table 2 Brief descriptive statistics of suspended solids concentrations data of sedimentation basins from peatlands.

\begin{tabular}{|c|c|c|c|c|c|c|c|c|c|c|c|c|}
\hline Peatlands & $\mathrm{P} 1$ & $\mathrm{P} 2$ & $\mathrm{P} 3$ & P4 & P5 & P6 & $\mathrm{P} 7$ & P8 & P9 & P10 & P11 & $\mathrm{P} 12$ \\
\hline Mean $\left(\mathrm{mg} \cdot \mathrm{L}^{-1}\right)$ & 10.94 & 11.65 & 10.01 & 4.90 & 14.42 & 9.30 & 5.27 & 13.37 & 7.48 & 13.64 & 8.78 & 8.69 \\
\hline $\operatorname{Median}\left(\mathrm{mg} \cdot \mathrm{L}^{-1}\right)$ & 10.00 & 8.50 & 6.00 & 4.17 & 10.00 & 7.88 & 4.00 & 10.51 & 6.94 & 13.63 & 8.88 & 7.00 \\
\hline $\operatorname{Minimum}\left(\mathrm{mg} \cdot \mathrm{L}^{-1}\right)$ & 2.50 & 2.00 & 2.00 & 2.00 & 3.50 & 0.50 & 0.00 & 2.17 & 2.83 & 6.80 & 3.00 & 4.00 \\
\hline $\operatorname{Maximum}\left(\mathrm{mg} \cdot \mathrm{L}^{-1}\right)$ & 21.00 & 39.00 & 37.00 & 11.00 & 61.75 & 24.88 & 12.00 & 56.00 & 15.33 & 22.33 & 17.33 & 23.00 \\
\hline Number of samples & 16 & 20 & 17 & 15 & 18 & 17 & 20 & 20 & 20 & 20 & 20 & 19 \\
\hline
\end{tabular}

P1 to P12 symbolize the peatlands; the highest and the lowest values of suspended solids concentrations are in bold characters. 


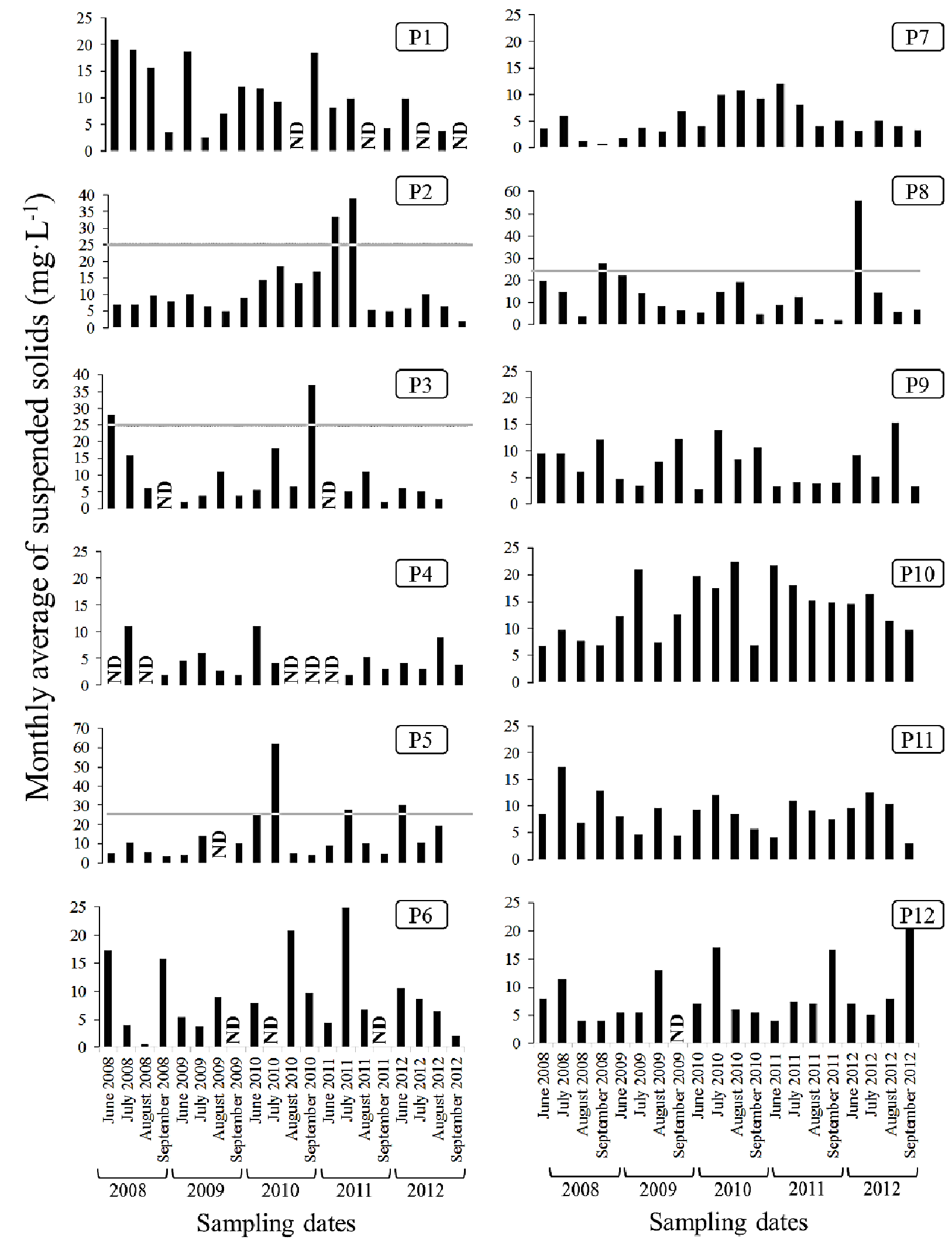

Fig. 3 Temporal evolution of the concentration of suspended solids from 2008 to 2012 in summer. ND: no data; P1 to P12 symbolize the peatlands; on some graphs, the horizontal grey line represents the $25 \mathrm{mg} \cdot \mathrm{L}^{-1} \mathrm{standard}$ for the Canadian guidelines for water quality for the protection of aquatic life. 
values and with a very close mean and median values $\left(13.64 \mathrm{mg} \cdot \mathrm{L}^{-1}\right.$ and $\left.13.63 \mathrm{mg} \cdot \mathrm{L}^{-1}\right)$, the concentrations of suspended solids ranged from $6.80 \mathrm{mg} \cdot \mathrm{L}^{-1}$ (June 2008) to $22.33 \mathrm{mg} \cdot \mathrm{L}^{-1}$ (August 2010). Similarly to P10, P11 presented close mean and median values $\left(8.78 \mathrm{mg} \cdot \mathrm{L}^{-1}\right.$ and $8.88 \mathrm{mg} \cdot \mathrm{L}^{-1}$ ) with nearly identical values around $10 \mathrm{mg} \cdot \mathrm{L}^{-1}$. At $\mathrm{P} 11$, the concentrations of suspended solids were between $3.00 \mathrm{mg} \cdot \mathrm{L}^{-1}$ in September 2012 and $17.33 \mathrm{mg} \cdot \mathrm{L}^{-1}$ in July 2008. Finally, all the measured values at $\mathrm{P} 12$ were lower than $23.00 \mathrm{mg} \cdot \mathrm{L}^{-1}$, with a minimum value of concentration of suspended solids at $4.00 \mathrm{mg} \cdot \mathrm{L}^{-1}$ calculated for August 2008 and September 2008.

\subsection{Characterization of the Climate Events}

In the case of this study, some climate events were analyzed. Because they could greatly influence a peat erosion by wind and/or water, data analysis was focused on the accumulated monthly precipitations and the speed of maximal gust (Table 3).

In summers from 2008 to 2012, the rain events were not always comparable from one year to another and from one weather station to another. The correlation matrix reveals no clear closeness between the three weather stations $(0.38<R<0.63)$; and it was the same for months comparison $(-0.02<R<0.31)$ (Table 3). The results interpretation took facts into account that: (1) summer rains could be very local; (2) weather stations considered were not located on the experimental sites. By considering the three weather stations, in 2008, no clear trend was observed about the rainfall. On the contrary, for the other years, the highest rainfalls were mainly recorded in June and July in 2009 and in September in 2010. In 2011, an almost equality of accumulated precipitations was noticed for June and July. In 2012, peaks of rainfall were mostly observed in June. By considering all data, the lower accumulated monthly precipitation (15.70 $\mathrm{mm}$ ) was recorded in August 2010 and the highest one $(164.80 \mathrm{~mm})$ in September 2010 both at Low-Caraquet; the mean, the median and the modal values were estimated at $88.27,93.10$ and $111.20 \mathrm{~mm}$, respectively (Table 3 ).

The speed of maximal gust was also heterogeneous from one year to another considering the three weather stations in summers from 2008 to 2012. The correlation matrix between the three weather stations revealed a similarity between values from Low-Caraquet and Miscou-Island $(R=0.93)$. Otherwise, by comparing the 4 months of all considered years, there was no clear correlation $(0.16$ $<R<0.63$ ) (Table 3). By taking all data into account, the lower speed of maximal gust $\left(32.67 \mathrm{~km} \cdot \mathrm{h}^{-1}\right)$ was recorded in June 2011 at Low-Caraquet and the highest one $\left(44.50 \mathrm{~km} \cdot \mathrm{h}^{-1}\right)$ was in September 2010 at Miscou-Island; the mean, the median and the modal values were estimated at $36.61,36.48$ and 36.94 $\mathrm{km} \cdot \mathrm{h}^{-1}$, respectively (Table 3 ).

In 2008, the highest values of wind for the three stations were recorded in September, and the lowest values were observed in June and July, except for Miramichi for which the minimum value was noticed in August. In 2009, the minimum value was observed at Low-Caraquet in July and the uppermost in August at Miscou-Island. In 2010, the maximum value was noticed at Miscou-Island in September and the lowermost in August at Miramichi. In 2011, the lowest value was observed at Low-Caraquet in June and the highest in September at Miscou-Island. In 2012, the peak value was noticed at Miscou-Island in September and the smallest value in July at Miramichi.

\section{Discussion}

4.1 Suspended Solids Concentrations: Spatial and Temporal Variability

For the comparison of the concentration of suspended solids between sites, whatever the years, the result of the Friedman test $\chi^{2}=42.32, d f=11, p=$ $1.00 \mathrm{E}-05)$ revealed the presence of significant differences among some of the 12 studied sedimentation basins: $\mathrm{P} 2$ versus $\mathrm{P} 4, \mathrm{P} 4$ versus $\mathrm{P} 10, \mathrm{P} 4$ 
Table 3 Monthly temporal evolution of climate parameters (accumulated precipitation $(\mathrm{mm})$ and speed of maximal gust $\left(\mathrm{km} \cdot \mathrm{h}^{-1}\right)$, respectively at the left and right side) recorded at three weather stations and correlation matrices of months, then weather stations. Sparkline graphs are illustrated at the right side of each sub-tables.

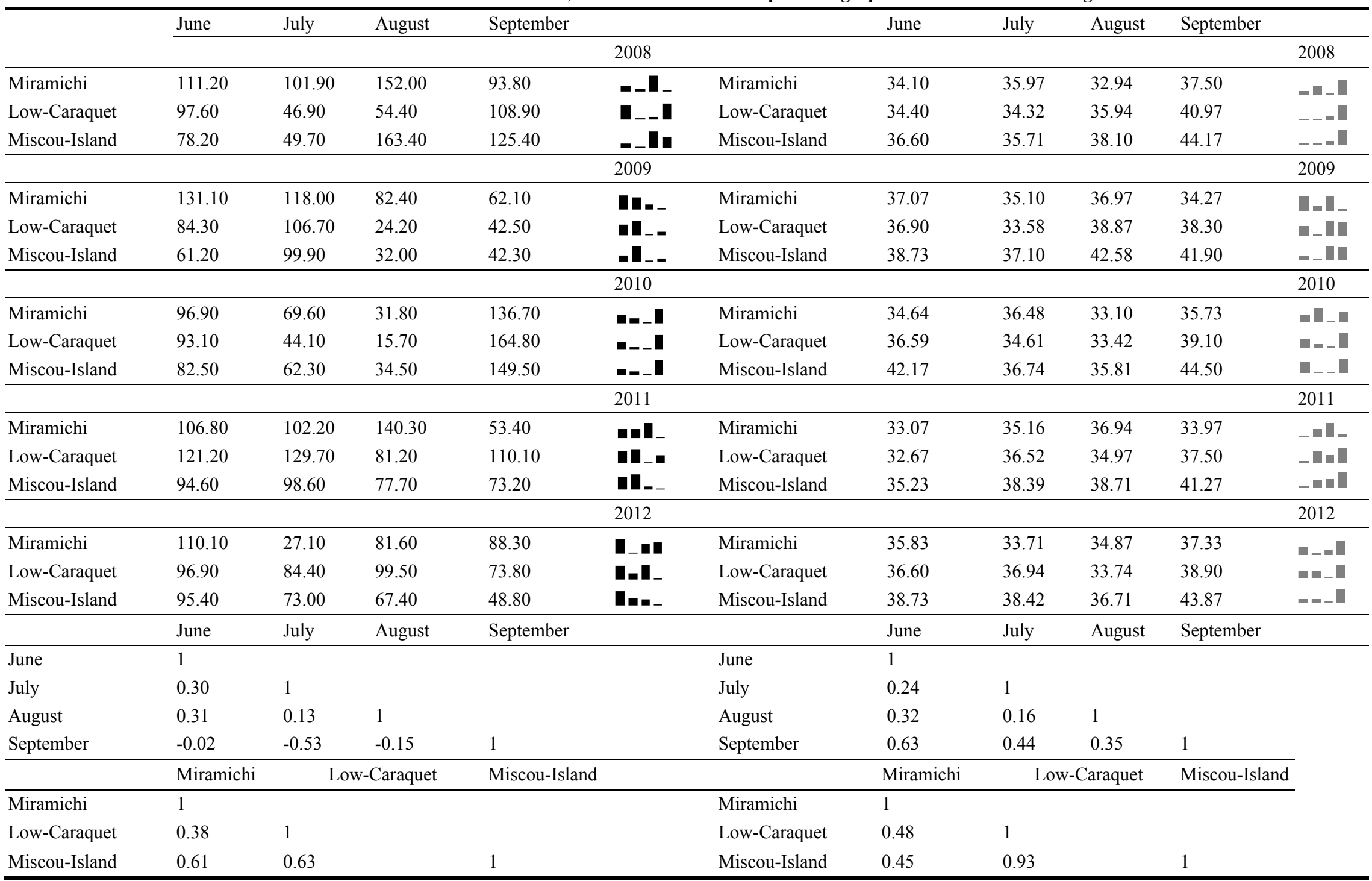


versus $\mathrm{P} 11$, and $\mathrm{P} 7$ versus $\mathrm{P} 10$. By taking all the years whatever the location of sites into account, the result of the Friedman test $\left(\chi^{2}=6.28, d f=4, p=1.79 \mathrm{E}-01\right)$ showed no significant difference among the 5 years considered. Finally, by considering each month whatever the years and the studied sites, the result of the Friedman test $\left(\chi^{2}=17.81, d f=3, p=4.80 \mathrm{E}-04\right)$ indicated the existence of just one significant difference between July and September.

Besides the statistical analyses, the lowest values of concentrations of suspended solids were mainly observed in September (for two-thirds of sites); and the highest ones in June and July (with three highest values) (Fig. 3). Some exceptions were noticed: the highest value for P3 and P12 were estimated in September $2010\left(37.00 \mathrm{mg} \cdot \mathrm{L}^{-1}\right)$ and September 2012 (23.00 $\left.\mathrm{mg} \cdot \mathrm{L}^{-1}\right)$, respectively; the lowest values for P9 and P10 were observed in June $2010\left(2.83 \mathrm{mg} \cdot \mathrm{L}^{-1}\right)$ and June $2008\left(6.80 \mathrm{mg} \cdot \mathrm{L}^{-1}\right)$, respectively. Otherwise, based on all the sedimentation basins of all peatlands and by comparing the months of each year relative to each other, the calculation of correlation matrix demonstrated a resemblance between values obtained for months of July 2009 and $2012(R=0.77)$, for months of September 2011 and $2012(R=0.81)$, and between September 2008 and June $2012(R=0.70)$. This observation implied a seasonality probably related to the seasonality of precipitation. From the comparison between months of each year, $50 \%$ of coefficients of correlation were inferior or equal to the absolute value of 0.30 ; and more than $75 \%$ of values of coefficients of correlation were inferior or equal to the absolute value of 0.50 .

These results on the concentration of suspended matters in the sedimentation basins of drained peatlands confirm those previously done in eastern New Brunswick [34-36], except that these previous studies were focused in spring and autumn with continuous measurements. The results acquired for the suspended solids rate in this case of study could probably be explained by climate events (excessive precipitations or winds) or by the knowing of the maintenance conditions of sedimentation basins.

\subsection{Suspended Solids Concentrations Related to Climate Events}

In the context of agricultural soils, the assessment of the amount of suspended solids released in the water system is usually done by software and models. Among many of them, it could be cited the USLE (universal soil loss equation) model [37, 38], the SWAT (soil and water assessment tool) model $[39,40]$, and the STREAM (sealing and transfer by runoff and erosion in relation with agricultural management) software [41, 42]. For estimating soil loss by erosion, these models and software take several parameters related to climate, soil physical properties and vegetation/land cover or land use into account. More specifically with respect to the land cover, they are interested in the nature, the density, and the presence/absence of vegetation cover. Considering the soil, they focus on the topography, the crusting, the erodibility, the particle size distribution, and the structural stability. And about the climate, they are primarily concerned with rainfall erosivity and precipitation amounts.

In the context of the study, all these cited parameters were unavailable making theses software and models un-adapted for the studied sites. The best and simple method to assess the CSS in the sedimentation basins of the drained peatlands is to sample the water and then calculate it by sieving. Nevertheless, knowing that the slope, the precipitations and the winds could greatly influence the loss of peat particles, the relationship between these factors and the CSS was verified. The statistical tests reveal that the CSS was insignificantly correlated exclusively with precipitation $(R=-0.01)$, and this results confirm those of Ref. [36]. Then, from the preceding results, based on peatlands P4, P6, P9, P10, P11 and P12, a simple function that allows calculating the CSS has been derived. By knowing the accumulated monthly 
precipitation $(P$ in $\mathrm{mm})$, the mean value of the slope on the peatlands ( $S$ in \%), and the speed of the wind $\left(W\right.$ in $\left.\mathrm{km} \cdot \mathrm{h}^{-1}\right)$, the $C S S\left(\mathrm{mg} \cdot \mathrm{L}^{-1}\right)$ can be expressed as:

$$
\begin{gathered}
C S S=57.59 \times S+7.18 \times \sqrt{\log _{10}(W)}- \\
0.35 \times \sqrt{P} \quad(n=111)
\end{gathered}
$$

This function can be considered acceptable with a $R$, a $R^{2}$, a $M A E$ and a $M A P E$, respectively evaluated at $0.87 \%, 0.76 \%, 4.01 \%$ and $3.61 \%$. The $S E$ measuring the degree of error in predicting CSS calculated (via the proposed formula) from CSS measured was estimated at 1.47. From Eq. (4), an estimation of the CSS can rapidly be done just by using the slope and simple weather parameters that are easy to obtain.

\subsection{Suspended Solids Impacts}

The role of sedimentation basins is not always accomplished: an optimal sedimentation efficiency was not permanently reached, allowing a release of particles in the water system. Indeed, a previous study done by Es-Salhi et al. [36] in New Brunswick demonstrated that the rate of suspended matters from sedimentation basin of drained peatlands exceeded 25 $\mathrm{mg} \cdot \mathrm{L}^{-1}$ several times; the same observation was found in a study completed during the spring season in Ref. [34]. Thus, the peatlands drainage is one of the causes of an excess of solids suspension in the water system. These suspended matters lead to environment changes. The ecological impacts that could be caused by suspended solids in the water system may affect the water quality, and then the environment and the ecosystem [43]. Depending on the hydrograph and the speed of flow of the water entering in the water system, the shape of the latter could be modified by creating new areas of sedimentary deposits. Also, the color of the water may be darken because of the increase of turbidity [26]. But the most problematic impact could certainly be related to the aquatic biota. Indeed, Laine [44] showed how the consequences of the drainage of peatlands can affect the size and the eating habits of salmon. High CSS could even cause anoxia in a standing water or a water with lowest flows. There are several parameters allowing to determine the effect of the suspended solids on aquatic biota including impacts on fishes living in the hydrographic network [45-47]. Among others, the main factors are the concentration, the chemical composition, the physical properties (particle-size distribution, particles shape and degree of peat decomposition) and the residence time of the various particles in the water. Further investigation concerning these latter factors on the 12 sites will precisely give an idea of the ecological impacts of the measured suspended solids concentrations on the aquatic life.

\section{Conclusion}

This study found that the amount of suspended matters in peatlands sedimentation basins of the east coastal zone of New Brunswick did not always meet the environmental standards of the province. Water from these sedimentation basins are among those that join the streams and surrounding rivers being an integral part of the hydrographic system of the watersheds in that region of New Brunswick. Thus, the knowledge of the water state and the water quality of these sedimentation basins through this study was important, especially since it is a region where the largest peat industry production in Canada is concentrated. Undertaken on some sites, the recent managements of abandoned peatlands will initiate a long-term monitoring program to study the impact of agro-ecological management on the quality and quantity of suspended solids in Canadian peatlands sedimentation basins.

\section{Acknowledgments}

Sincere thanks go to the Associations of New Brunswick peat producers. The authors also thank Fanny Turgeon for the data collection within the framework of her training course; and André St-Hilaire from INRS-ETE for his reading of the manuscript. 


\section{References}

[1] Lappalainen, E. 1996. Global Peat Resources. Finland: International Peat Society.

[2] Clarke, D., and Joosten, H. 2002. Wise Use of Mires and Wetlands. Background and Principles Including a Framework for Decision-Making. Totnes, UK: International Mire Conservation Group/International Peat Society.

[3] Armstrong, A., Holden, J., Kay, P., Foulger, M., Gledhill, S., McDonald, A. T., and Walker, A. 2009. "Drain-Blocking Techniques on Blanket Peat: A Framework for Best Practice." Journal of Environmental Management 90 (11): 3512-9.

[4] Freeman, C., Fenner, N., and Shirsat, A. H. 2012. "Peatland Geoengineering: An Alternative Approach to Terrestrial Carbon Sequestration." Philosophical Transactions of the Royal Society A 370: 4404-21.

[5] 2012. International Mire Conservation Group Newsletter Issue 2012/2. IMCG biennial report 2010-2012. Accessed July 13, 2014. http://www.imcg.net/media/newsletter/ nl1202.pdf.

[6] Benavides, J. C. 2014. "The Effect of Drainage on Organic Matter Accumulation and Plant Communities of High-Altitude Peatlands in the Colombian Tropical Andes." Mires and Peat 15 (1): 1-15.

[7] Whatley, M. H., Loon, E. E., Dam, H., Vonk, J. A., Geest, H. G., and Admiraal, W. 2014. "Macrophyte Loss Drives Decadal Change in Benthic Invertebrates in Peatland Drainage Ditches." Freshwater Biology 59 (1): 114-26.

[8] Joosten, H. 2009. "The Global Peatland $\mathrm{CO}_{2}$ Picture. Peatland Status and Emissions in All Countries of the World." Draft Produced for the Proceedings of Wetlands International, Ede. UN-FCCC Meetings in Thailand, Bangkok. Accessed July 13, 2014. https://unfccc.int/files/kyoto_protocol/application/pdf/dra ftpeatlandco2report.pdf.

[9] Hooijer, A., Page, S., Jauhiainen, J., Lee, W. A., Lu, X. X., Idris, A., and Anshari, G. 2012. "Subsidence and Carbon Loss in Drained Tropical Peatlands." Biogeosciences 9: 1053-71.

[10] Moore, T. R., and Knowles, R. 1989. "The Influence of Water Table Levels on Methane and Carbon Dioxide Emissions from Peatland Soils." Canadian Journal of Soil Science 69 (1): 33-8.

[11] Burlo, A., Minke, M., Chuvashova, H., Augustin, J., Hoffmann, M., and Narkevitch, I. 2014. "Greenhouse Gas Emissions of Drained Fen Peatlands in Belarus Are Controlled by Water Table, Land Use, and Annual Weather Conditions.” In Geophysical Research Abstracts,
European Geoscience Union General Assembly, edited by European Geosciences Union. Göttingen, Germany: the Copernicus GmbH (Copernicus Publications).

[12] Hooijer, A., Page, S., Canadell, J. G., Silvius, M., Kwadijk, J., Wösten, H., and Jauhiainen, J. 2010. "Current and Future $\mathrm{CO}_{2}$ Emissions from Drained Peatlands in Southeast Asia." Biogeosciences 7: 1505-14.

[13] Kurnianto, S., Warren, M., Talbot, J., Kauffman, B., Murdiyarso, D., and Frolking, S. 2014. "Carbon Accumulation of Tropical Peatlands over Millennia: A Modeling Approach." In Global Change Biology. Accessed July 31, 2014. http://onlinelibrary.wiley. com/doi/10.1111/gcb.12672/pdf.

[14] Holden, J., Chapman, P. J., and Labadz, J. C. 2004. "Artificial Drainage of Peatlands: Hydrological and Hydrochemical Process and Wetland Restoration." Progress in Physical Geography 28 (1): 95-123.

[15] Schwärzel, K., Renger, M., Sauerbrey, R., and Wessolek, G. 2002. "Soil Physical Characteristics of Peat Soils." Journal of Plant Nutrition and Soil Science 165 (4): 479-86.

[16] Kechavarzi, C., Dawson, Q., and Leeds-Harrison, P. B. 2010. "Physical Properties of Low-Lying Agricultural Peat Soils in England." Geoderma 154 (3): 196-202.

[17] Sundström, E., Magnusson, T., and Hånell, B. 2000. "Nutrient Conditions in Drained Peatlands along a North-South Climatic Gradient in Sweden." Forest Ecology and Management 126 (2): 149-61.

[18] Gundogan, R., Hall, N., Demirkiran, A. R., Aydemir, S., and Korkmaz, H. 2010. "The Effects of Artificial Drainage on Soil Characteristics of a Peatland Ecosystem in Southeast Turkey." Fresenius Environmental Bulletin 19 (10): 2239-45.

[19] Daniels, S. M., Agnew, C. T., Allott, T. E. H., and Evans, M. G. 2008. "Water Table Variability and Runoff Generation in an Eroded Peatland, South Pennines, UK." Journal of Hydrology 361 (1): 214-26.

[20] Holden, J., and Burt, T. P. 2003. "Runoff Production in Blanket Peat Covered Catchments." In Water Resources Research. Accessed July 29, 2003. http://onlinelibrary.wiley.com/doi/10.1029/2002WR0019 56/pdf.

[21] Katimon, A., Shahid, S., Khairi Abd Wahab, A., and Ali, M. H. 2013. "Hydrological Behaviour of a Drained Agricultural Peat Catchment in the Tropics. 1: Rainfall, Runoff and Water Table Relationships." Hydrological Sciences Journal 58 (6): 1297-309.

[22] Nieminen, M., Ahti, E., Nousiainen, H., Joensuu, S., and Vuollekoski, M. 2005. "Capacity of Riparian Buffer Zones to Reduce Sediment Concentrations in Discharge 
from Peatlands Drained for Forestry." Silva Fennica 39 (3): $331-9$.

[23] Scholz, M., and Sadowski, A. J. 2009. "Conceptual Classification Model for Sustainable Flood Retention Basins." Journal of Environmental Management 90 (1): 624-33.

[24] Robinson, M., Scholz, M., Bastien, N., and Carfrae, J. 2010. "Classification of Different Sustainable Flood Retention Basin Types." Journal of Environmental Sciences 22 (6): 898-903.

[25] Kalbitz, K., and Geyer, S. 2002. "Different Effects of Peat Degradation on Dissolved Organic Carbon and Nitrogen." Organic Geochemistry 33 (3): 319-26.

[26] Armstrong, A., Holden, J., Kay, P., Francis, B., Foulger, M., Gledhill, S., and Walker, A. 2010. "The Impact of Peatland Drain-Blocking on Dissolved Organic Carbon Loss and Discolouration of Water; Results from a National Survey." Journal of Hydrology 381 (1): 112-20.

[27] Rees, H. W., Fahmy, S. H., Wang, C., and Wells, R. E. 2005. Soils of Central and Northern New Brunswick. Fredericton, New Brunswick: Potato Research Centre, Agriculture and Agri-Food.

[28] Wiken, E. B. 1986. The Eco-zones of Canada, Series of the Ecological Classification of the Territory. 19th Head Office of Lands Publication. Ottawa: Environment Canada Press.

[29] Tramblay, Y., St-Hilaire, A., and Ouarda, T. B. 2008. "Frequency Analysis of Maximum Annual Suspended Sediment Concentrations in North America." Hydrological Sciences Journal 53 (1): 236-52.

[30] Marttila, H., and Kløve, B. 2010. "Dynamics of Erosion and Suspended Sediment Transport from Drained Peatland Forestry." Journal of Hydrology 388 (3): 414-25.

[31] Lenore, S. C., Arnold, E. G., and Andrew, D. E. 1998. Standard Methods for the Examination of Water and Wastewater. 20th ed.. Washington, DC: American Public Health Association/American Water Works Association/Water Environment Federation.

[32] Environment Canada. 2014. "Climate Data in Canada 1981-2010.” Environment Canada. Accessed August 11, 2014. http://www.climat.meteo.gc.ca/.

[33] Canadian Council of the Ministers of the Environment. 2008. Canadian Guidelines for Water Quality. Winnipeg: Canadian Council of the Ministers of the Environment.

[34] St-Hilaire, A., Courtenay, S. C., Diaz-Delgado, C., Pavey, B., Ouarda, T. B., Boghen, A., and Bobée, B. 2006. "Suspended Sediment Concentrations Downstream of a Harvested Peat Bog: Analysis and Preliminary Modelling of Exceedances Using Logistic Regression." Canadian Water Resources Journal 31 (3): 139-56.

[35] Pavey, B., Saint-Hilaire, A., Courtenay, S., Ouarda, T., and Bobée, B. 2007. "Exploratory Study of Suspended Sediment Concentrations Downstream of Harvested Peat Bogs." Environmental Monitoring and Assessment 135 (1-3): 369-82.

[36] Es-Salhi, M. A., Clément, M., St-Hilaire, A., Caissie, D., and Courtenay, S. C. 2013. "Influence of Hydrological Conditions and Peat Extraction Operations on Suspended Sediment Concentration and Deposition in the East Branch Portage River, New Brunswick (Canada)." Water Quality Research Journal of Canada 48 (4): 305-20.

[37] El Garouani, A., Merzouk, A., and Ozer, A. 2003. "Mapping and Quantitative Evaluation of the Hydric Erosion in the Moroccan Pré-Rif." In Proceedings of an International Symposium on Hydrology of the Mediterranean and Semiarid Regions, 380-8.

[38] Sadeghi, S. H. R., Gholami, L., Khaledi Darvishan, A., and Saeidi, P. 2014. "A Review of the Application of the MUSLE Model Worldwide." Hydrological Sciences Journal 59 (2): 365-75.

[39] Saxton, K. E., and Rawls, W. J. 2006. "Soil Water Characteristic Estimates by Texture and Organic Matter for Hydrologic Solutions." Soil Science Society of America Journal 70 (5): 1569-78.

[40] Oeurng, C., Sauvage, S., and Sánchez-Pérez, J. M. 2011. "Assessment of Hydrology, Sediment and Particulate Organic Carbon Yield in a Large Agricultural Catchment Using the SWAT Model." Journal of Hydrology 401 (3): 145-53.

[41] Le Bissonnais, Y., Couturier, A., Cerdan, O., Papy, F., Martin, P., Souchere, V., Bruno, J. F., Lebrun, P., Fox, D., Morschel, J., and Elyakime, B. 2006. "Control of the Hydric Erosion of Cultivated Soils Physical Phenomena and Devices of Action." In Proceedings of the Workshop of the Days of Exchanges and Forward-Looking on the Thematic: From Soil Research to Public Decision, 29-31.

[42] Couturier, A., Daroussin, J., Darboux, F., Souchère, V., Le Bissonnais, Y., Cerdan, O., and King, D. 2013. "Improvement of Surface Flow Network Prediction for the Modeling of Erosion Processes in Agricultural Landscapes." Geomorphology 183: 120-9.

[43] Clément, M., St-Hilaire, A., Caissie, D., Chiasson, A., Courtenay, S., and Hardie, P. 2009. "An Evaluation of Mitigation Measures to Reduce Impacts of Peat Harvesting on the Aquatic Habitat of the East Branch Portage River, New Brunswick, Canada." Canadian Water Resources Journal 34 (4): 441-52. 
Point Estimates and Climate Effects on the Environment

[44] Laine, A. 2001. "Effects of Peatland Drainage on the Size and Diet of Yearling Salmon in a Humic Northern River." Archivfür Hydrobiologie 151 (1): 83-99.

[45] Kemp, P., Sear, D., Collins, A., Naden, P., and Jones, I. 2011. "The Impacts of Fine Sediment on Riverine Fish." Hydrological Processes 25 (11): 1800-21.

[46] Jones, J. I., Murphy, J. F., Collins, A. L., Sear, D. A.,
Naden, P. S., and Armitage, P. D. 2012. "The Impact of Fine Sediment on Macro-Invertebrates." River Research and Applications 28 (8): 1055-71.

[47] Tuukkanen, T., Marttila, H., and Kløve, B. 2014. "Effect of Soil Properties on Peat Erosion and Suspended Sediment Delivery in Drained Peatlands." Water Resources Research 50: 3523-35. 